\title{
Movements of dead fish in rivers
}

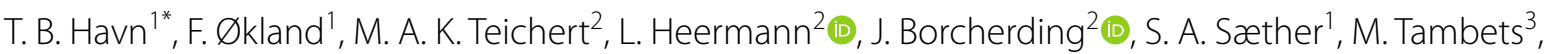 \\ O. H. Diserud ${ }^{1}$ and E. B. Thorstad ${ }^{1}$
}

\begin{abstract}
Background: The aim of telemetry studies is often to determine the fate and mortality rates of fish. A moving fish is usually regarded as alive and a long-term stationary fish as dead — and the site where it became stationary as the site where it died. Downstream transport of dead fish in rivers can lead investigators to mistake dead fish for live fish. We examined downstream movements of 60 dead Atlantic salmon smolts and 55 dead European silver eels, equipped with radio transmitters and released at hydropower stations in three German rivers.

Results: Overall, dead smolts drifted up to $2.4 \mathrm{~km}$ downstream and dead eels up to at least $30.1 \mathrm{~km}$ downstream. Smolts released in an Archimedes screw turbine drifted up to $1.1 \mathrm{~km}$ and eels up to at least $5.1 \mathrm{~km}$ downstream. Most smolts stopped moving further downstream within 1 week after release, whereas the eels (or their transmitters) moved downstream over several weeks, or even months, after release. However, the distance moved varied considerably also within species and among release sites. Eighteen (30\%) dead smolts and nine (16\%) dead eels moved upstream or disappeared from the rivers, indicating that they had been taken by scavengers. Some of these (four smolts and one eel) had recordings, indicating that they had been taken out of the river by birds.

Conclusions: Fish can drift considerable distances downstream after they have died in a river. This can make it difficult to identify dead fish, and the exact site and time of death from telemetry studies. Furthermore, dead fish can be moved within the river, or taken out of the river, by scavengers. These results are relevant for studies of mortality at power stations, but also for studies of tagged fish in rivers in general. When designing telemetry studies and interpreting telemetry data, investigators should keep in mind that dead fish (or their transmitters) may drift downstream. Investigators may also consider if it is useful to release dead fish as a control groups when planning and performing fish mortality studies.
\end{abstract}

Keywords: Mortality estimate, Telemetry, Radio tag, Atlantic salmon, Salmo salar, European eel, Anguilla anguilla, Smolt, Silver eel, Downstream drift

\section{Background}

The aim of telemetry studies is often to determine the fate and mortality rates of fish marked with electronic tags [e.g., 1, 2]. A moving fish is usually regarded as alive, while a long-term stationary fish is regarded as deadand the site where it became stationary is regarded as the site where it died [e.g., 3, 4]. However, this may not always be correct.

First, tagged fish can be eaten by a predator, and the recordings may reflect the behavior of the predator

\footnotetext{
*Correspondence: Torgeir.Havn@nina.no

1 Norwegian Institute for Nature Research, NINA, P.O. Box 5685, Sluppen,

7485 Trondheim, Norway

Full list of author information is available at the end of the article
}

instead of the tagged fish, which can create misleading conclusions. Thorstad et al. [5] documented that acoustic transmitters of eaten Atlantic salmon Salmo salar may remain in fish predators up to 47 days. Tags with depth sensors can sometimes be used to determine whether tagged fish are alive or have been predated, if the tagged fish and the predators differ in vertical behavior $[5,6]$. Predation of tagged fish has also been documented by applying mixture models or cluster analyses to analyze fish movement patterns $[7,8]$. Predation by marine mammals has been documented by use of tags with temperature sensors [6].

Second, downstream transport of dead fish in rivers can lead investigators to mistake dead fish for live fish. 
Calles et al. [2] performed one of the few studies in which fish was experimentally released to assess the extent of drifting by dead individuals. Based on release of six dead European eels Anguilla anguilla into hydropower turbines, drift of dead fish up to $4.2 \mathrm{~km}$ downstream was demonstrated. Such downstream movements of dead fish have implications for calculating mortality rates and identifying site of mortality in telemetry studies. However, there is little available information on potential downstream movement of dead fish in rivers.

In the present study, downstream movements of dead Atlantic salmon smolts and European silver eels were examined in three German rivers. Dead fish were tagged with radio transmitters and released at three hydropower stations: in tailraces, in an Archimedes screw turbine, in a spillway gate and on top of a movable turbine (Fig. 1). The aim was to study the potential for downstream movement of dead fish in rivers.

\section{Methods}

\section{Study sites}

The study was performed at three German run-of-theriver hydropower stations, which were the Unkelmühle (River Sieg), Gengenbach (River Kinzig) and Kuhlemühle (River Diemel) power stations. The Sieg is a 153-km-long tributary to the Rhine, with a catchment area of $2862 \mathrm{~km}^{2}$ and an average water discharge of $53 \mathrm{~m}^{3} \mathrm{~s}^{-1}$ at the confluence with the Rhine. The Kinzig is a $93-\mathrm{km}$-long tributary to the Rhine, with a catchment area of $1406 \mathrm{~km}^{2}$ and an average water discharge at the Gengenbach release site of $23 \mathrm{~m}^{3} \mathrm{~s}^{-1}$. The Diemel is a $110-\mathrm{km}$-long tributary to the Weser, with a catchment area of $1762 \mathrm{~km}^{2}$ and an average discharge of $16 \mathrm{~m}^{3} \mathrm{~s}^{-1}$ at Helmarshausen.

In total, 60 dead smolts (mean total length $15.4 \mathrm{~cm}$, range 9.1-19.0 cm, SD 2.2) and 55 dead silver eels (mean total length $79.0 \mathrm{~cm}$, range $57.5-94.0 \mathrm{~cm}, \mathrm{SD} 6.5$ ) were released (Additional file 1). Smolts were obtained from the Albaum hatchery for release in the Sieg and Diemel and from the Lachszucht Wolftal hatchery for release in the Kinzig. Eels were obtained from fishers in the Mosel and Rhine. Before tagging and release, smolts were killed by an overdose of benzocaine (aethylium $p$-aminobenzoicum) and a blow to the head. Eels were killed by an overdose of metomidate, and their spinal cord was cut by a knife. Radio transmitters were surgically implanted into the body cavity by using methods described by Finstad et al. [9] for smolts and by Thorstad et al. [10] for eels.

The fish were tagged with individually coded radio transmitters (Lotek Wireless Inc., Canada). Smolts were tagged with Nano-tags model NTQ-2 (frequency $151.500 \mathrm{MHz}$, dimensions $5 \times 3 \times 10 \mathrm{~mm}$; weight in air/ water $0.31 / 0.20 \mathrm{~g}$, pulse rates $2.0-7.2 \mathrm{~s}$, expected lifetime 16-38 days dependent on pulse repetition rates).
Eels were tagged with tag model NTQ-6-2 (frequency $150.300-150.340 \mathrm{MHz}$, dimensions $9 \times 30 \mathrm{~mm}$; weight in air/water 4.3/2.6 g, pulse rates $2.0-7.2 \mathrm{~s}$, minimum guaranteed lifetime 172 days).

The dead fish were released in the tailrace downstream of the power station in the Sieg and the Diemel, on top of a movable Kaplan bulb turbine (capacity of $20 \mathrm{~m}^{3} \mathrm{~s}^{-1}$ ) in the Kinzig, in a four-bladed Archimedes screw turbine (3.4 $\mathrm{m}$ diameter and $7 \mathrm{~m}$ long) in the Diemel and in a spillway gate in the Sieg (Fig. 1; Additional file 1). The Archimedes screw turbine was running at 24 revolutions per minute, with water discharge through the turbine of $5 \mathrm{~m}^{3} \mathrm{~s}^{-1}$. In our study area, the Sieg and the Diemel are meandering rivers, whereas the Kinzig is channelized. All have a gravel-dominated substrate in the study area, but the Diemel is strongly sedimented in areas of low flow. The slope of the river stretch where smolts and eels drifted, respectively, was 0.8 and $0.2 \%$ in the Sieg, 0 and $0.1 \%$ in the Diemel and 1.3 and $0.1 \%$ in the Kinzig.

\section{Recording of tagged fish after release}

Tagged fish were manually tracked by boat, cycling and walking along the rivers, using a portable receiver (Lotek SRX 600) and a three-element Yagi antenna (Additional file 2). For smolts, a stretch from the release site to $7.5-29.0 \mathrm{~km}$ downstream was covered by manual tracking and for eels from the release site to $11.1-44.2 \mathrm{~km}$ downstream.

The fish were also recorded by stationary receivers (Lotek SRX 600), which stored information on time and ID of tagged fish when they were within the antenna detection ranges. At most sites in most years, a stationary receiver was installed $5.0-7.5 \mathrm{~km}$ downstream from the release site (Additional file 2). In each river, there were also two stationary receivers upstream of the release sites, situated between $1.2-2.5$ and $4.2-8.3 \mathrm{~km}$ upstream of the power stations. Upstream receivers were not installed to monitor dead fish, but were installed in relation to other studies. Recordings from these receivers were used to indicate whether dead fish had been taken by scavengers, bringing them upstream. Detailed monitoring at the power stations was done by using a network of stationary receivers with 5-18 antennas at each station.

\section{Data analyses}

Data analysis and creating figures were conducted in $\mathrm{R}$ version 3.3.1 [11]. Fish that were considered as taken by scavengers were fish with transmitter signals moving upstream (e.g., registrations upstream of the power station), or fish that disappeared from the river between two receiver sites. Tags with movements past upstream receiver sites that were too fast to have been made by mammal or fish scavengers were regarded as taken by 

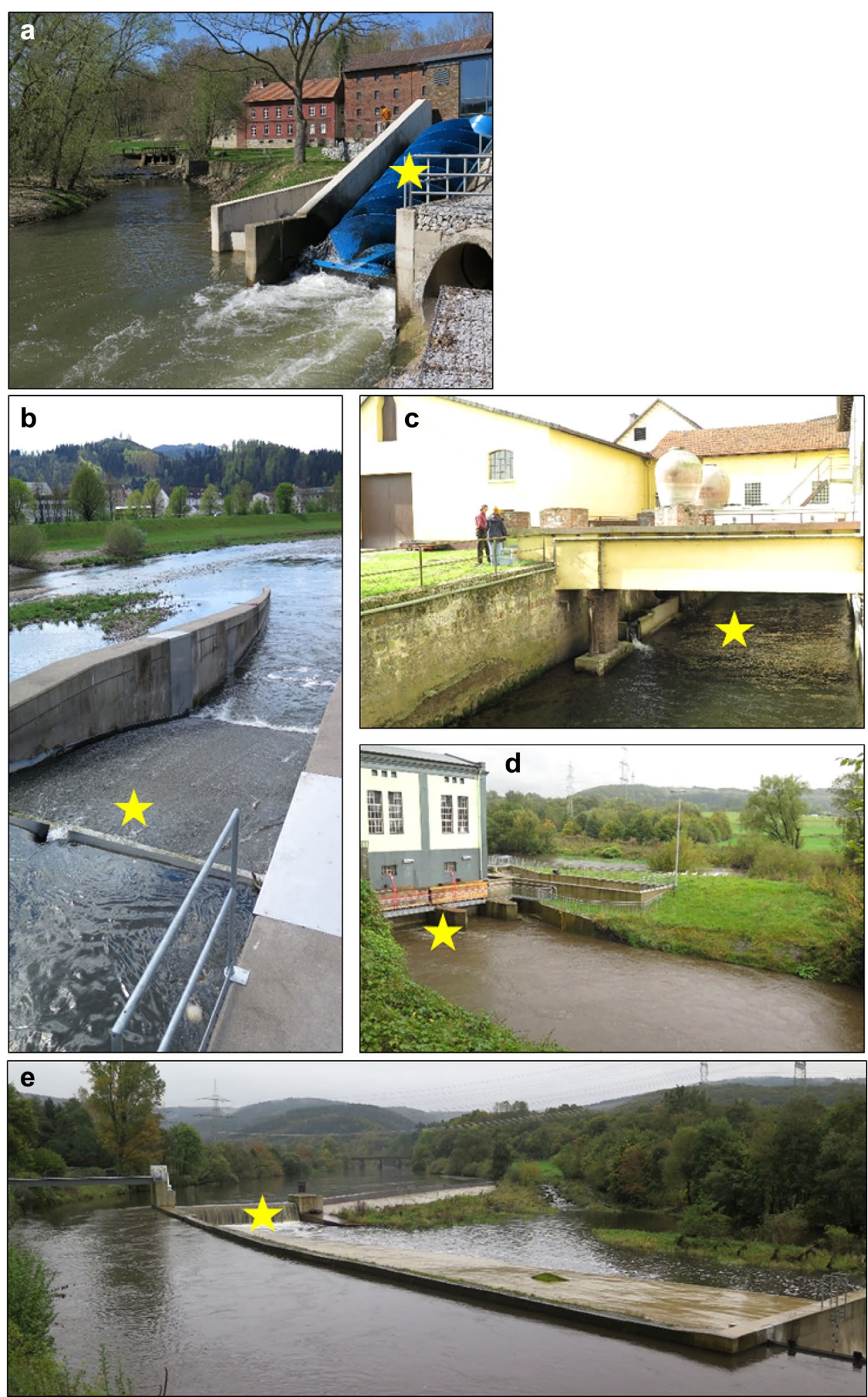

Fig. 1 Release sites of dead Atlantic salmon smolts and European silver eels. Release sites of dead Atlantic salmon smolts and European silver eels indicated by yellow stars: $\mathbf{a}$ in an Archimedes screw turbine in the Diemel, $\mathbf{b}$ on top of movable bulb turbine in the Kinzig, $\mathbf{c}$ in a tailrace of two Francis turbines in the Diemel, $\mathbf{d}$ in a tailrace in the Sieg and $\mathbf{e}$ in a spillway gate in the Sieg 
avian scavengers. These tags were also often registered on two separate receiver sites simultaneously, which could only be possible if signal range was increased by transmitters being in air.

\section{Results \\ Drift distances of dead Atlantic salmon smolts and European silver eels}

Smolts drifted up to $2.4 \mathrm{~km}$ downstream from the release site (Table 1; Fig. 2; Additional file 3). The maximum distance drifted varied among release sites and dates, from 0 to $2.4 \mathrm{~km}$ (Table 1). Most of the dead smolts drifted only a few meters or few hundred meters downstream. Median drift distance of the release groups ranged from 0 to $1.5 \mathrm{~km}$ (Table 1 ).

European silver eels drifted up to $30.1 \mathrm{~km}$ downstream from the release site (Table 1; Fig. 2; Additional files 4, 5). This is a minimum estimate, because three eels in the Kinzig reached the confluence with the Rhine. Tracking could not be performed further downstream, due to the size of the Rhine and the subsequently low detection probability. It is therefore unknown how much further than $30.1 \mathrm{~km}$ they may have drifted. The maximum distance drifted varied considerably among release sites and dates also for eels, from 2.9 to $30.1 \mathrm{~km}$ (Table 1). Most of the dead eels drifted several kilometers downstream from the release site, with median drift distances of the different release groups ranging from 0.5 to $14.6 \mathrm{~km}$ (Table 1).

In all cases, the eels drifted longer distances downstream than smolts, when comparing groups released at the same sites (Table 1; Additional files 3, 4,5). This difference cannot be explained by differences in water discharge, because the discharge at release was not consistently higher for eels than for smolts released at the same sites (Table 1). Average water discharge or maximum flood level in the period after release also did not seem to fully explain the difference between the species: Although higher average discharge and larger floods were experienced by eels than by smolts released in the tailrace in the Sieg, this was not the case at the other sites (Table 1; Additional files 3, 4, 5).

Dead eels in general moved downstream over longer time periods after release than dead smolts did (Table 1; Additional files 3, 4, 5). Most of the smolts did not move downstream later than 1 week after release, and median time from release to last recorded movement varied among release groups, from 0.5 to 13 days (Table 1 ). The last downstream movement recorded by any smolt was 26 days after release. However, this could be an underestimate since it is limited by the battery lifetime of the transmitters. In contrast, median time from release to last recorded movement for groups of eels ranged from 5.0 to 55 days (Table 1). The last downstream movement recorded by any eel was after 108 days. Of a total of 41 eel transmitters recorded in the winter and spring the year after release, 12 (29\%) had a downstream movement during that period.

\section{Impacts of water discharge}

Water discharge at release and average water discharge in the period after release did not seem to impact distance drifted in either smolt or eel (Additional file 6). In eel, but not in smolt, high floods in the period after release seemed to result in the longest drift distances (Additional file 6). However, impacts of water discharge are difficult to assess based on these data, since they include fish released at different sites, the sample sizes within groups are small, and site-specific effects may obscure the impact of water discharge. If we compare groups within each of the species that are released at the same site, but at different dates and, hence, different water discharges, this confirms that there is not a clear relationship between distance drifted and water discharge at and after release (Table 1).

\section{Fish taken by scavengers}

Eighteen (30\%) dead smolts (mean body length $15.6 \mathrm{~cm}$, range 10.0-18.2, SD 2.1) and nine (16\%) dead eels (mean body length $80.9 \mathrm{~cm}$, range 57.5-94.0, SD 10.1) moved upstream or disappeared from the rivers between two receiver sites, indicating that they had been taken by scavengers (Additional file 1). Five of these (four smolts with body length $14.3-16.8 \mathrm{~cm}$ and one eel with body length $84.0 \mathrm{~cm}$ ) had signal recordings indicating that they had been taken out of the river by birds.

\section{Discussion}

Hydropower stations influence migrating fishes in many ways. Besides a delay in migration, turbines and other installations at power stations may cause injury and mortality in downstream migrating fish [e.g., 12-14]. Telemetry is a useful tool to monitor the behavior of fish during passage of hydropower stations and other sites impacted by anthropogenic activities. However, mortality is difficult to document, since fish that die during passage of a hydropower station may drift further downstream, as demonstrated in the present study, and their movements can incorrectly be regarded as movements of live fish. The results from this study are relevant for studies at power stations, but also for studies of tagged fish in rivers in general.

Dead fish (or their transmitters) moved considerable distances downstream, smolts up to $2.4 \mathrm{~km}$ downstream and eels up to at least $30.1 \mathrm{~km}$, which are longer distances than indicated in previous studies $[2,15]$. Since the fish were killed before release, these results represent 


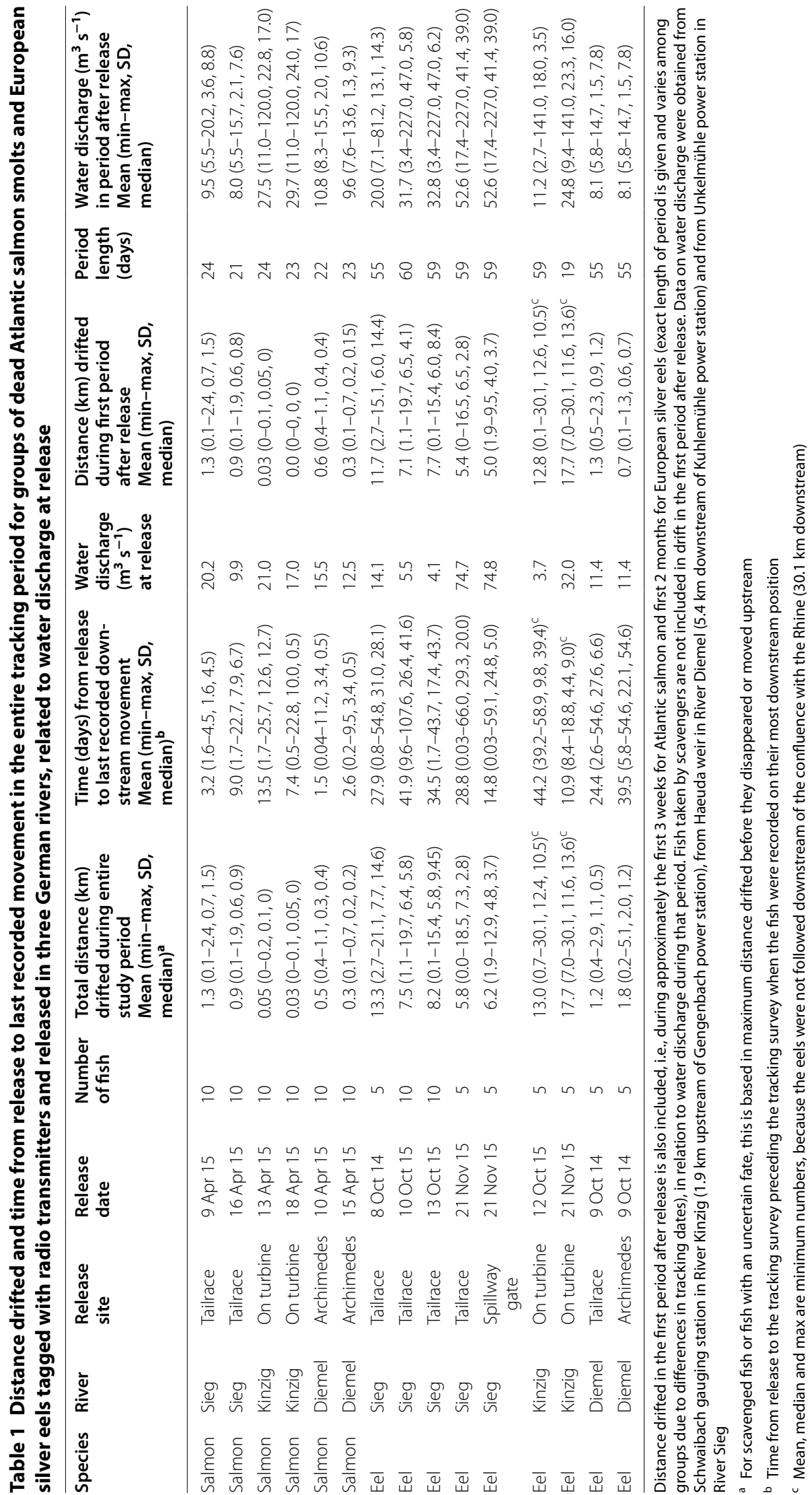



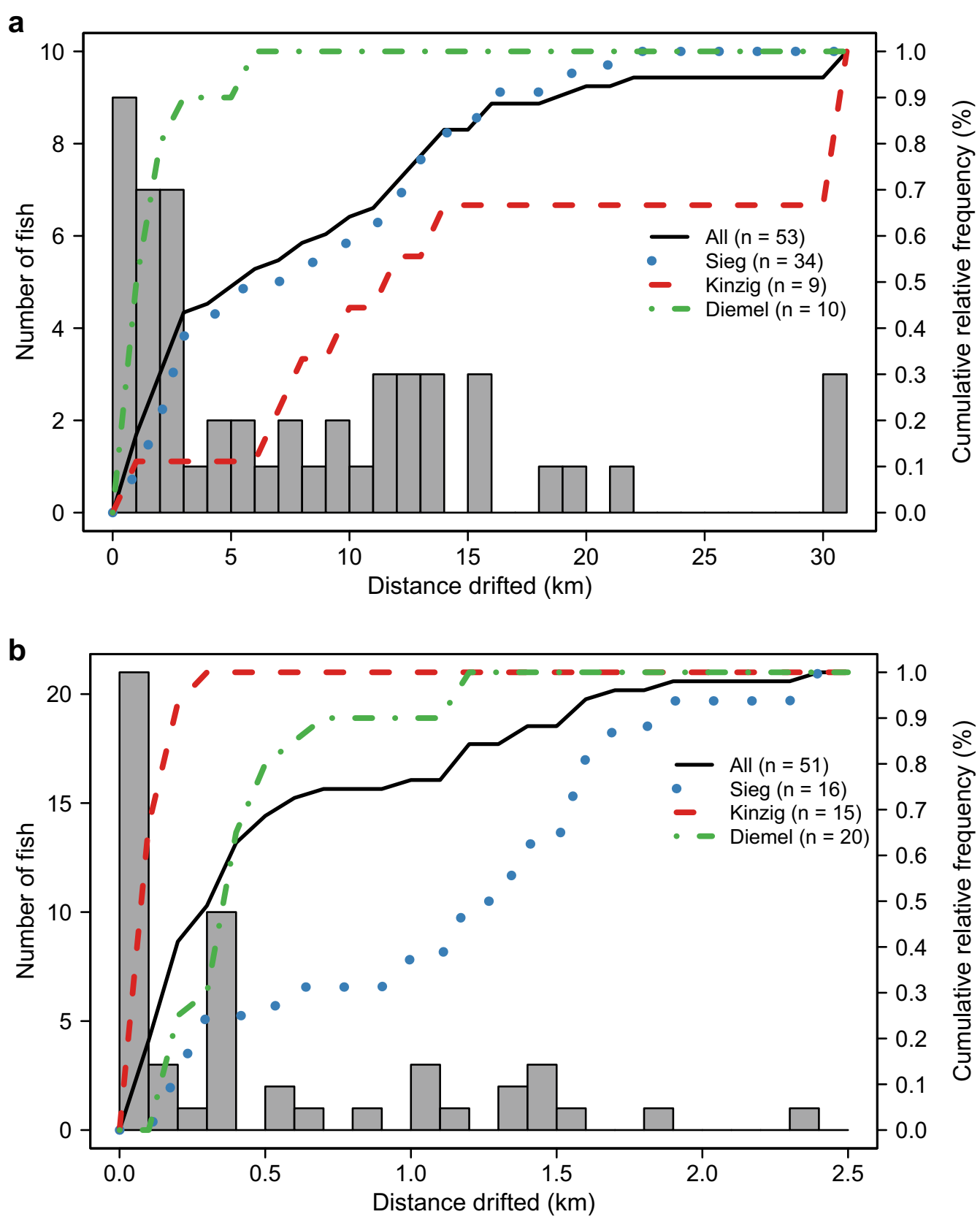

Fig. 2 Frequency distribution of maximum distance drifted for dead European silver eels (a) and Atlantic salmon smolts (b). Maximum distance drifted after release for individual dead European silver eels (a) and Atlantic salmon smolts $(\mathbf{b})$. The cumulative relative frequency distributions of drift distance drifted in the Sieg (blue line), Kinzig (red line), Diemel (green line) and for all fish (black line) are also included. For scavenged fish or fish with an uncertain fate, maximum distance drifted before they disappeared or moved upstream is used. If they were never found during tracking surveys or registered by receiver sites after release, they are excluded from this analysis. Bin width is $1 \mathrm{~km}$ for eel and $0.1 \mathrm{~km}$ for smolts

downstream drift after immediate mortality. If fish are mortally wounded, but still perform some swim-like movements, it is possible that they may move even longer distances downstream from the site where they were wounded. We suggest that the downstream drift distance can be affected by many factors, such as water discharge, water currents at the site where fish died and in the areas downstream, magnitude of floods, river morphology, substrate, fish size and decay rate of the dead fish. Our study design did not allow for an in-depth analysis of the effect of different factors. Nevertheless, since releases were made of two species, at a number of different rivers, 
and under different conditions, the results are relevant for a wide range of conditions. Our results clearly show that there is large variation in drift distance both within and among release occasions and that information on drift distances is not necessarily transferable among sites and situations.

In general, the eels moved longer distances downstream than the smolts. Although individuals of the two species were not released at the same time, they were released at the same sites, and the difference between the species could not be explained by consistently higher water discharges during releases of eels. The transmitters used for smolts had shorter battery lifetime than those used for eels, and the smolts were therefore monitored for a shorter time period. Still, many smolts (or transmitters) were followed for 1.5 month or more, and during a similar period, most eels had already moved much longer distances than recorded for smolts. Most smolts had stopped moving long before the transmitter stopped sending signals. Hence, a shorter transmitter lifetime for smolts cannot explain the different drift distances between the species. Other factors causing different drift distances could be differences in body size and body consistency, which may influence the speed and nature of the decay process. Smolts are small compared to adult salmon and silver eels, and previous records of floating carcasses of adult salmon up to $20 \mathrm{~km}$ downstream [15] may suggest that the short drift distance of smolts in the present study was related to their smaller size.

Dead European silver eels drifted downstream over longer time periods than smolts, even when considering the difference in battery lifetime. Similar to the adult salmon in the study of Hewson [15], the drift of eels seemed to be facilitated by large floods in the period after release. Downstream movements of dead eels still occurred after 1.5-3.5 months, but we do not know whether the carcass still existed, or whether it was only the tag moving. The carcass of larger fish may remain for a longer time period than of smaller fish. The decay rate may also be slower at lower temperatures in the autumn, which may have contributed to a longer time period of downstream drift by eels than by smolts. Tags may drift downstream after the carcass has disappeared, and the different size and weight of the tags may also have impacted the extent to which they settled on the bottom.

A relatively large proportion of the dead fish moved upstream or disappeared from the rivers $(30 \%$ of the smolts and $16 \%$ of the eels), indicating that they had been taken by scavengers. We cannot rule out that a few transmitters failed, but it is unlikely that this happened with a large proportion of the transmitters. Hence, the most likely reason for transmitters disappearing from the river is that they were taken by scavengers. This was supported by the fact that several dead fish showed movements indicating that they had been brought out of the river by birds. High predation rates in areas close to power stations are documented in several studies, and birds such as red-necked grebe Podiceps griseigena, grey heron Ardea cinerea and great cormorant Phalacrocorax carbo are known as fish predators [1, 16-18]. Great cormorants, grey heron and goosander Mergus merganser were avian predators present in our study areas (own observations). The fact that dead fish may be moved around in rivers, and even brought out of rivers by scavengers, has to be taken into account when attempting to make inferences about mortality causes and sites from telemetry data.

Information on the movements and fate of dead fish can be used to design telemetry studies and analyze telemetry data. In studies when it is not possible or desirable to include groups of dead fish, results in this and similar papers can be used to design the study to minimize problems with possible dead fish being interpreted as live fish. If the study area covers a long enough river stretch, identification of probable survivors after for instance passing a power station can be based on stationary receivers installed further downstream than dead fish likely drift. The present results indicate that assessment of European silver eel mortality requires a larger study area than assessment of Atlantic salmon smolt mortality. Large study areas may be feasible in long rivers, such as the Rhine. However, if recording mortality at a power station located close to the river mouth, where dead fish can potentially drift into the sea, it may be more difficult to obtain reliable mortality estimates. If groups of dead fish can be released as part of the study, the distribution of dead fish drift distances can be used to estimate probabilities of mortality for fish being released alive, based on their movement distance. It may also be possible in some situations to distinguish dead from survived fish based on information on the dead fish other than distribution of drift distances, like movement speed or distinctive aspects of behavior, such as movements indicating that they have been taken by scavengers. At one power station, we used recordings of dead smolts to estimate the probability of detecting mortality of live smolts potentially killed when passing an Archimedes screw and Francis turbines, based on both movement distance and the proportion of fish disappearing from the river [19]. We were able to estimate a probable upper threshold of the true mortality and the uncertainty in the estimate [19].

\section{Conclusions}

In conclusion, investigators must take into account that fish equipped with electronic tags in rivers can drift considerable distances downstream after they have died 
and that this can make it difficult to identify mortality, and the exact site and cause of death. Also, dead fish can be moved within the river, or taken out of the river, by scavengers. The long drift distances and drift periods recorded for eels indicate that it may be particularly challenging to evaluate eel mortality for instance at a hydropower station. Release of dead fish can be used as a control group in telemetry studies and help evaluate mortality specifically for each study.

\section{Additional files}

Additional file 1. Groups of dead Atlantic salmon smolts and European silver eels tagged with radio transmitters and released in three German rivers. Information on fish taken by scavengers in these groups is also given. $\mathrm{nd}=$ not detected.

Additional file 2. Overview of manual tracking surveys for radio tagged dead Atlantic salmon smolts and European silver eels in three German rivers. Maximum distance surveyed during manual tracking downstream from the release site is given, but the entire distance was not tracked during all surveys. The positions of downstream stationary receivers are also given.

Additional file 3. Downstream drift of individual dead Atlantic salmon smolts released (a) in the tailrace in the Sieg on 9 and 16 April $(n=20)$, (b) on the turbine in the Kinzig on 13 and 18 April $(n=20)$, and (c) in the Archimedes screw turbine in the Diemel on 10 and 15 April $2015(n=20)$. The position of smolts during each tracking survey or when they passed receiver sites are shown as individually colored points with lines between. The last registration of fish taken by a scavenger is marked with an $\mathrm{S}$. Water discharge (black line) is also shown. Note that the scales on the $y$-axes differ.

Additional file 4. Downstream drift of individual dead European silver eels released in the Sieg (a) in the tailrace on 8 October $2014(n=5)$, (b) in the tailrace on 10 October $2015(n=10)$, (c) in the tailrace on 13 October $2015(n=10)$, and (d) in the tailrace (colored points) or spillway gate (colored triangles) 21 November $2015(n=10)$. The position of eels during each tracking survey or when they passed receiver sites are shown as individually colored points with lines between. The last registration of fish taken by a scavenger is marked with an $\mathrm{S}$. Water discharge (black line) is also shown.

Additional file 5. Downstream drift of individual dead European silver eels released (a) on the turbine in the Kinzig on 12 October and 21 November $2015(n=10)$, and (b) in the Archimedes screw turbine (colored points) and tailrace of a Francis turbine (colored triangles) in the Diemel on 9 October $2014(n=10)$. The position of eels during each tracking survey or when they passed receiver sites are shown as individually colored points with lines between. The last registration of fish taken by a scavenger is marked with an S. Water discharge (black line) is also shown. In the Kinzig, eels that drifted out of the tracked stretch and entered the Rhine is indicated with an R. In the Diemel, eels that disappeared from the river during the winter when monitoring was suspended are indicated with a U. Note that the scales on the $y$-axes differ.

Additional file 6. Median distance drifted after release for groups of dead European silver eels (black triangles) and Atlantic salmon smolts (red points) after approximately 3 weeks (smolts) and 2 months (eels) in relation to (a) water discharge at release, (b) mean water discharge in the period, and (c) maximum water discharge in the period. Error bars represent minimum and maximum distances drifted.

\section{Authors' contributions}

TBH participated in the design and field work and was a major contributor in data analyses and writing the manuscript. $F \varnothing, M A K T, L H, J B$ and MT were involved in study design, field work, interpreting the data and revising the manuscript critically. SAS participated in field work, data analyses and writing the manuscript. OHD participated in data analyses and writing the manuscript. EBT participated in the design, field work and data analyses and was a major contributor in writing the manuscript. All authors read and approved the final manuscript.

\section{Author details}

${ }^{1}$ Norwegian Institute for Nature Research, NINA, P.O. Box 5685, Sluppen, 7485 Trondheim, Norway. ${ }^{2}$ Institute for Zoology, General Ecology and Limnology, University of Cologne, Zülpicher Str. 47b, 50674 Cologne, Germany. ${ }^{3}$ Wildlife Estonia, Veski 4, Tartu 51005, Estonia.

\section{Acknowledgements}

We would like to thank Detlev Ingendahl for good collaboration and the companies E-Werke Mittelbaden and Hydroenergie Roth, Innogy SE and Warburger Brauerei Kohlschein for the possibility to perform the study at their power stations. We would like to thank Leon Barthel, Gerhard Feldhaus, Matthias Fleckhammer, Michael Kohlschein, Florian Kreische, Marc Dickert, Toni Kröber, Laura Mehner, Nico Menge, Andreas Pilgram, Stefan Scheffels, Matthias Sommer, Marc Steinheuer, Anna Stiller, Stephan Wagner, Sebastian Wantia, Armin Zoschke, Michael Holtegel and colleagues at the LANUV hatchery Albaum and Svenja Schwarzkopf and colleagues at Lachszucht Wolftal hatchery for invaluable help during fieldwork and two anonymous reviewers for comments to an earlier version of the manuscript.

\section{Competing interests}

The authors declare that they have no competing interests.

\section{Availability of data and materials}

The datasets analyzed during the current study are available from the corresponding author on reasonable request.

\section{Ethics approval and consent to participate}

The study was designed and performed in compliance with German animal welfare law and was approved by the ethics commission of the North RhineWestphalian State Agency for Nature, Environment and Consumer Protection (LANUV) to the University of Cologne (JB). A permission (\#84-02.04.2014.A011) was given based on article 8(1) of the German animal welfare law and article 33 of the North Rhine-Westphalian regulation for the protection of animals used for experimental purposes.

\section{Funding}

Results presented were obtained as part of studies commissioned by the Ministry for Climate Protection, Environment, Agriculture, Conservation and Consumer Protection of the State of North Rhine-Westphalia (MKULNV), funded through the State Agency for Nature, Environment and Consumer Protection of North Rhine-Westphalia (LANUV) to the University of Cologne (JB). However, planning and execution of the study was conducted independently and under the sole responsibility of the authors.

Received: 19 October 2016 Accepted: 3 March 2017

Published online: 23 March 2017

\section{References}

1. Jepsen N, Aarestrup K, Økland F, Rasmussen G. Survival of radio-tagged Atlantic salmon (Salmo salar L.) and trout (Salmo trutta L.) smolts passing a reservoir during seaward migration. Hydrobiology. 1998;372:347-53.

2. Calles O, Olsson IC, Comoglio C, Kemp PS, Blunden L, Schmitz M, Greenberg LA. Size-dependent mortality of migratory silver eels at a hydropower plant, and implications for escapement to the sea. Freshw Biol. 2010;55:2167-80.

3. Carr JW, Whoriskey FG. Migration of silver American eels past a hydroelectric dam and through a coastal zone. Fish Manag Ecol. 2008;15:393-400.

4. Havn TB, Uglem I, Solem $\varnothing$, Cooke SJ, Whoriskey F, Thorstad EB. The effect of catch-and-release angling at high water temperatures on behavior and survival of Atlantic salmon during spawning migration. J Fish Biol. 2015;87:342-59. 
5. Thorstad EB, Uglem I, Finstad B, Chittenden CM, Nilsen R, Økland F, Bjørn PA. Stocking location and predation by marine fishes affect survival of hatchery-reared Atlantic salmon smolts. Fish Manag Ecol. 2012;19:400-9.

6. Wahlberg M, Westerberg H, Aarestrup K, Feunteun E, Gargan P, Righton D. Evidence of marine mammal predation of the European eel (Anguilla anguilla L.) on its marine migration. Deep-Sea Res. 2014;(86):32-8.

7. Romine JG, Perry RW, Johnston SV, Fitzer CW, Pagliughi SW, Blake AR. Identifying when tagged fishes have been consumed by piscivorous predators: application of multivariate mixture models to movement parameters of telemetered fishes. Anim Biotelem. 2014;2:3.

8. Gibson AJF, Halfyard EA, Bradford RG, Stokesbury MJW, Redden AM. Effects of predation on telemetry-based survival estimates: insights from a study on endangered Atlantic salmon smolts. Can J Fish Aquat Sci. 2015;72:728-41.

9. Finstad B, Økland F, Thorstad EB, Bjørn PA, McKinley RS. Migration of hatchery-reared Atlantic salmon and wild anadromous brown trout postsmolts in a Norwegian fjord system. J Fish Biol. 2005;66:86-96.

10. Thorstad EB, Økland F, Westerberg H, Aarestrup K, Metcalfe JD. Evaluation of surgical implantation of electronic tags in European eel and effects of different suture materials. Mar Freshw Res. 2013;64:324-31.

11. R Core Team. R: A language and environment for statistical computing. R Foundation for Statistical Computing, Vienna, Austria 2016. https:// www.R-project.org/.

12. Durif C, Elie P, Gosset C, Rives J, Travade F. Behavioural study of downstream migrating eels by radio-telemetry at a small hydroelectric power plant. Am Fish Soc Symp. 2003;33:343-56.
13. Calles $\mathrm{O}$, Greenberg L. Connectivity is a two-way street-the need for a holistic approach to fish passage problems in regulated rivers. River Res Appl. 2009;25:1268-86.

14. Stich DS, Zydlewski GB, Kocik JF, Zydlewski JD. Linking behavior, physiology, and survival of Atlantic salmon smolts during estuary migration. Mar Coast Fish. 2015;7:68-86.

15. Hewson R. Use of salmonid carcasses by vertebrate scavengers. J Zool. 1995;235:53-65.

16. Doherty D, McCarthy K. The population dynamics, foraging activities and diet of great cormorants (Phalacrocorax carbo carbo L.) in the vicinity of an Irish hydroelectricity generating station. Suppl Ric Biol Selvaggina 1997;26:133-43.

17. Aarestrup K, Jepsen N, Rasmussen G, Økland F. Movements of two strains of radio tagged Atlantic salmon, Salmo salar L., smolts through a reservoir. Fish Manag Ecol. 1999;6:97-107.

18. Koed A, Jepsen N, Aarestrup K, Nielsen C. Initial mortality of radio-tagged Atlantic salmon (Salmo salar L.) smolts following release downstream of a hydropower station. Hydrobiology. 2002;483:31-7.

19. Havn TB, Sæther SA, Thorstad EB, Teichert MAK, Heermann L, Diserud OH, Borcherding J, Tambets M, Økland F. Downstream migration of Atlantic salmon smolts past a low head hydropower station equipped with an Archimedes screw turbine. Ecol Eng. 2017 (in revision).

\section{Submit your next manuscript to BioMed Central and we will help you at every step:}

- We accept pre-submission inquiries

- Our selector tool helps you to find the most relevant journal

- We provide round the clock customer support

- Convenient online submission

- Thorough peer review

- Inclusion in PubMed and all major indexing services

- Maximum visibility for your research

Submit your manuscript at www.biomedcentral.com/submit
O Biomed Central 